Visualizing the Street 
Cities and Cultures is an interd isciplinary humanities book series addressing the interrelations between contemporary cities and the cultures they produce. The series takes a special interest in the impact of globalization on urban space and cultural production, but remains concerned with all forms of cultural expression and transformation associated with contemporary cities.

Series editor:

Christoph Lindner, University of Amsterdam

Advisory Board:

Ackbar Abbas, University of California, Irvine

Nezar AlSayyad, University of California, Berkeley

Derek Gregory, University of British Colombia

Stephanie Hemelryk Donald, University of New South Wales

Shirley Jordan, Queen Mary, University of London

Geoffrey Kantaris, University of Cambrigde

Bill Marshall, University of London

Ginette Verstraete, VU University Amsterdam

Richard J. Williams, University of Edinburgh 


\title{
Visualizing the Street
}

\author{
New Practices of Documenting, \\ Navigating and Imagining the City
}

Edited by

Pedram Dibazar and Judith Naeff 
Cover photo by Pedram Dibazar and Judith Naeff

Cover design: Coördesign, Leiden

Lay-out: Crius Group, Hulshout

$\begin{array}{ll}\text { ISBN } & 9789462984356 \\ \text { e-ISBN } & 9789048535019 \text { (pdf) } \\ \text { DOI } & 10.5117 / 9789462984356 \\ \text { NUR } & 670\end{array}$

(c) P. Dibazar, J.A. Naeff / Amsterdam University Press B.V., Amsterdam 2019

All rights reserved. Without limiting the rights under copyright reserved above, no part of this book may be reproduced, stored in or introduced into a retrieval system, or transmitted, in any form or by any means (electronic, mechanical, photocopying, recording or otherwise) without the written permission of both the copyright owner and the author of the book.

Every effort has been made to obtain permission to use all copyrighted illustrations reproduced in this book. Nonetheless, whosoever believes to have rights to this material is advised to contact the publisher. 